\title{
Painavaa kielioppia
}

Fred Karlsson: Finnish - A comprehensive grammar. Routledge Comprehensive Grammars. London: Routledge 2017. $499 \mathrm{~s}$. ISBN 978-1-138-82103-3.

Fred Karlssonin Finnish - A comprehensive grammar on päivitetty ja laajennettu versio kirjoittajan useilla kielillä ja monina painoksina viime vuosikymmeninä ilmestyneestä kieliopista. Teoksen lähtökohdaksi mainitaan (s. xiii) englanninkielinen Finnish - An essential grammar (Karlsson 2015 [1999]), mutta suurelta osin rakenne on säilynyt muuttumattomana ensimmäisestä, ruotsinkielisestä kieliopista (Karlsson 1978) lähtien. Routledge Comprehensive Grammars -sarjassa julkaistussa kieliopissa on kuitenkin paljon uutta: terminologiaa on päivitetty Ison suomen kieliopin (ISK 2004) mukaiseksi ja morfosyntaksin osuutta on laajennettu. Lisäksi esimerkistöä on päivitetty sekä sanaston että puhekielisten varianttien osalta (ks. esipuhe, s. xiii-xiv). Käsittelen kutakin näistä laajennuksista erikseen. Aluksi kuitenkin sananen kieliopin kohderyhmästä ja rakenteesta. ${ }^{1}$

Kustantajan (Routledge 2018) mukaan mainitun sarjan kohderyhmään kuuluvat keskitasoiset ja edistyneet kielenoppijat sekä kielentutkijat. Teoksella onkin selvästi kahtalainen funktio toisaalta pedagogisena käsikirjana ja toisaalta referenssikielioppina. Pedagogisena käsikirjana se toimii nähdäkseni lähinnä sillä edellytyksellä, että oppija on kykenevä ja motivoitunut kielen rakenteen itsenäiseen analyysiin. Esimerkiksi morfosyntaksin

1. Kiitän Hanna-Ilona Härmävaaraa arvion käsikirjoitukseen saamistani hyödyllisistä kommenteista. Tekstin puutteet ja epäjohdonmukaisuudet ovat luonnollisesti omalla vastuullani. osuudessa operoidaan osin sellaisilla käsitteillä, jotka tähtäävät ennemmin kielen systemaattiseen analyysiin kuin kielen oppimisen helpottamiseen (esim. erottelu yksinkertaisiin ja kompleksisiin lauseisiin). Toisaalta muun muassa puhekielen nosto esimerkkeihin kautta linjan voidaan nähdä ennen kaikkea kielenoppijalle suunnattuna ratkaisuna.

\section{Äänteistä lauseisiin, kirjoituksesta puheeseen}

Karlssonin kielioppi on tukeva paitsi sisällykseltään myös fyysiseltä olomuodoltaan: kovakantisen kirjan kesyttämiseen tarvitaan kaksi kättä tai painavia apuvälineitä. Teos sisältää esipuheen ja loppuliitteiden lisäksi 27 päälukua. Suomen sosiohistorialliseen kontekstiin ja kielellisiin ominaispiirteisiin kurkistavan johdannon jälkeen ensimmäisenä käsittelyyn pääsevät ääntäminen ja äännerakenne (luku 2), sanarakenteen yleisesittely (luku 3), äännevaihtelut (astevaihtelu ja $i: n$ aiheuttamat vaihtelut, luku 4) sekä nominien ja verbien taivutustyypit (luvut 5-6). Laajennettu morfosyntaksin osuus alkaa aiheen yleiskatsauksella (luku 7), joka pohjustaa niin ikään uusia lukuja lausekkeista (luku 8) ja lauseista (luvut 9-10). Seuraavina tulevat sijamuoto- ja possessiivisuffiksiluvut (1116) sekä sanaluokkaluvut $(17-18,25)$ ovat vanhaa perua. Kirjan lopussa käsitellään verbin taivutuskategorioita (luvut 19-23), komparaatiota (luku 24), sananmuodostusta (luku 26) ja lopulta puhutun kielen erityispiirteitä (luku 27).

Liitteenä on mittava, lähes 30-sivuinen taulukko, jossa eritellään kieliopissa käsiteltyjen taivutuspäätteiden kaikki mahdolliset morfologiset yhdistelmät erilaisiin 
vartaloihin liitettyinä. Taulukkoon on tiivistetty paljon informaatiota, mutta pienestä kirjasinkoostaan huolimatta se palvellee hyvin referenssinä, kun kielenoppija esimerkiksi törmää vieraaseen sananmuotoon. Hyödyllinen on myös toinen liite, jossa selitetään tiiviisti - ajoittain tosin hieman liikaakin yksinkertaistaen - kieliopin keskeisimmät käsitteet. Viimeisessä liitteessä esitellään suomea vieraana kielenä opiskelevalle soveltuvaa materiaalia. Listassa on kuitenkin myös teoksia, joiden kohderyhmä on toisaalla. Esimerkiksi rektiokirjallisuudesta mainitaan Pajunen (1999), jota paremmin oppijaa palvelisi Jönsson-Korholan ja Whiten (1997) teos.

\section{Ison suomen kieliopin jäljissä}

Teos seuraa ISK:a (2004) infinitiivien, partisiippien ja objektin (sijan) nimityksissä: ensimmäisiä kutsutaan niiden päätteisiin viittaavilla nimillä (esim. Ainfinitiivi ja NUT-partisiippi, vrt. 1. infinitiivi ja perfektipartisiippi), ja partitiiviobjektille oppositiossa on totaaliobjekti, jolloin akkusatiivi jää vain pronominien sijaksi. Infinitiivien (s. 344, 349, 354, 360) ja partisiippien käsittelyssä (s. 362) yhteys kirjoittajan aiemmin käyttämiin - ja partisiippien tapauksessa myös analyyttisempiin - termeihin tulee kirjassa havainnollisesti esiin. Objektinnimitysten (s. 191-195, 211-218) yhteyttä aiempaan akkusatiivitermin käyttöön ei osoiteta, mikä on myös ehdottomasti lukijaystävällistä, sillä akkusatiivin monimerkityksisyys todennäköisesti vain hämmentäisi lukijaa.

Termimuutosten lisäksi teokseen on päivitetty verbityyppien järjestys siten, että supistumaverbit (oppikirjoissa usein verbityyppi 4) seuraavat saada- (tyyppi 2) ja tulla-verbejä (tyyppi 3) (vrt. Karlsson 1978: 64-67; 2004: 70-74). ISK:n (2004 $\$ 71-75)$ tapaan verbityyppien nimitykset perustuvat kuitenkin numeroinnin (1-6) sijaan esimerkkiverbeihin (antaa-verbit, saada-verbit, tulla- ja nousta-verbit jne.; s. 103-110). Kaikki nämä muutokset helpottavat kieliopin käyttöä uudempien, enemmän tai vähemmän ISK:n terminologiaa hyödyntävien oppikirjojen rinnalla. Ennen kaikkea ne ovat kuitenkin osoituksia siitä, että ISK on vakiinnuttanut paikkansa ohittamattomana suomen kieliopin termien lähteenä.

\section{Morfosyntaksi ja kielen analyysi}

Seuraavaksi luon katsauksen eniten uutta sisältävään morfosyntaksin jaksoon (s. 116-173). Sen aloittaa aiheeseen johdattava luku 7 ("Interplay between Finnish morphology and syntax"), joka suuntaa lukijan huomion eksplisiittisesti siihen, että morfologian ja syntaksin vuorovaikutus on avain suomen kielen rakenteen ymmärtämiseen (s. 116). Esimerkiksi sijanmerkinnän ja syntaksin yhteispeli tulee havainnollisesti esiin (s. 118). Luvussa 8 ("Phrases") esitellään suomen lauseketyypit enimmäkseen ISK:n mukaisesti. Lähteestään poiketen Karlsson määrittelee kuitenkin erikseen numeraalilausekkeen havainnollistaakseen nominatiivimuotoisen numeraalin poikkeavaa syntaktista käyttäytymistä (s. 134-136; vrt. ISK $2004 \$ 789$ ).

Karlsson jakaa lauseet yksinkertaisiin (luku 9) ja kompleksisiin (luku 10), joista jälkimmäinen ei kuitenkaan viittaa vain yhdyslauseisiin (vrt. ISK $2004 \$ 882$ ), sillä jo negaatio, liittotempus tai infinitiivitäydennys tekevät lauseesta kompleksisen (s. 150, 161-162). Yksinkertainen lause voi siis Karlssonin kieliopin mukaan sisältää vain yhden verbin (s. 140). Jako on systemaattinen mutta poikkeuksellinen ja palvelee ehkä ennemmin kielen rakenteen kuvausta itseään kuin esimerkiksi kielenoppijaa. Oireeksi tästä voi tulkita sen, että vaikka kieltolause analysoidaan kompleksiseksi, käsitellään sitä etenemisjärjestyksen luonnollisuuteen vedoten jo yksinkertaisten lauseiden yhteydessä (s. 159-153). 
Syntaktiset lausetyypit Karlsson jakaa ensin tyypillisen sanajärjestyksen mukaan, jolloin (in)transitiivilauseet ovat ryhmässä SV (subjekti + verbi) ja erikoislausetyypit jakautuvat kahtia VS-lauseisiin ja subjektittomiin lauseisiin. VS-lauseista Karlsson nimeää eksistentiaalilauseen, omistuslauseen, elottoman omistuksen lauseen (inalienable possession clause), tuloslauseen ja kvanttorilauseen (s. 144-147), joista kahden viimeisen käsittely kuitataan pelkillä esimerkeillä. Vaikka on ymmärrettävää, ettei yksittäisiin lausetyyppeihin voi tällaisessa teoksessa syventyä, olisivat lyhyet luonnehdinnat olleet silti paikallaan. Ilman kommenttia jäävät myös eksistentiaalilauseiden alta löytyvät ilmiölauseet (s. 145), joiden erikoisuutena on tyhjä teemapaikka (esim. syttyi sota). Karlsson kommentoi myös sanajärjestyksen variaatioita todeten niiden kantavan painotuksen, informaatiorakenteen ja tekstin jäsentymisen tehtäviä (s. 148). Sanajärjestysvaihtoehtojen merkityseroja havainnollistetaan esimerkein, joiden tulkinta jätetään kuitenkin lukijan vastuulle (lukijaystävällisemmästä ratkaisusta ks. White 2006: 353-354).

Kompleksisten lauseiden käsittelyssä Karlsson hyödyntää ISK:n termiä verbiketju (verb chain) viitatessaan finittiverbiin, joka saa täydennyksekseen infinitiivitai partisiippilausekkeen (esim. menen nukkumaan, s. 162, 166), ja termiä verbiliitto (verb union) viitatessaan merkitykseltään kiteytyneeseen apu- ja pääverbilliseen rakenteeseen (esim. on oltava, s. 162, 382383). Sen sijaan hän poikkeaa ISK:n terminologiasta puhuessaan paljon tutkimistaan, kirjoitetussa suomessa toisinaan vastaantulevista, moninkertaisista lauseiden, infiniittisten rakenteiden ja nominaalistusten upotuksista (s. 170-171; ks. esim. Karlsson 2010). Kokonaisuudessaan morfosyntaksin luvut 7-10 tarjoavat hyvän johdatuksen suomen kielen rakenteeseen, mutta käsittelyä leimaa sisällön runsauden ja tilan vähyyden ristiriita, joka johtaa aika ajoin haastavan tiiviiseen ilmaisuun.

\section{Esimerkit ikkunana kieleen}

Esimerkeillä on aina merkittävä rooli kieliopin lukijan omaksuman kielen muotoutumisessa. Kieliopin esipuheessa mainitut lisäykset ja ajantasaistukset näkyvät kielioppia lukiessa: esimerkkejä on paljon, ja ne käsittelevät myös tämän päivän teemoja tietotekniikasta päivänpolitiikkaan. Myös epämuodollinen kielenkäyttö huomioidaan: kieliopissa muun muassa tekstaillaan ja löhötään (s. 106, 109), valaistaan kirosanan vittu syntaktista käyttäytymistä (s. 180, 201) sekä johdetaan sana räkälä (s. 421).

Esimerkit ovat sisällöllisesti enimmäkseen hyvin havainnollisia ja esittelevät idiomaattista suomen kieltä. Niiden muotoilut ja asettelut antavat kuitenkin aihetta muutamaan huomioon. Ensinnäkin Karlsson soveltaa läpi kieliopin hyvin yksityiskohtaista kielenainesten morfologista merkintätapaa: taivutusainesten erottamisen lisäksi (kahvi-a) osoitetaan kannan ja johtimen raja (tule $>v a>i s>$ uute-en, s. 378), yhdyssanan osien raja (kova=levy; matka= puh $>$ el>ime-t, s. 143) sekä astevaihtelun heikko aste $(+$ kaupungi-t). Plusmerkki juuri heikon asteen osoittimena vaikuttaa ensisilmäykseltä epäintuitiiviselta, mutta sen käyttö merkityksessä 'astevaihtelu on tapahtunut' toimii kyllä. Suuremman haasteen tuottaa merkintöjen valtava määrä, joka saa monet esimerkeistä muistuttamaan jonkinlaista koodikieltä: itse $>n a ̈ i s>y y s=p a ̈ i v a ̈-n a ̈ ~+p r e s i d e n t i-l l a ̈$ on vasta-an $=o t t>o$ (s. 256). Tällaisten merkkijonojen sujuva lukeminen edellyttää merkintätekniikan hyvää sisäistämistä. Jos siis esimerkit toimivat ikkunana kieleen, ovat sanojen virran katkaisevat merkit huuruisia kuvioita ikkunalasissa ja kieliopin lukijan on opittava tarkentamaan katseensa tarpeen mukaan joko tämän huuruisen lasin läpi sanojen kokonaisuuteen tai itse lasipinnan yksityiskohtiin eli kielen analyysiin. Hankalinta katkottuja esimerkkisanoja on lukea taulukoissa, joissa väli- 
merkit heittävät pieneen tilaan ahdetun sanan osat eri riveille (esim. s. 124).

Toiseksi lukijan työtä lisäävät muut asettelun heikkoudet ja selitteiden puutteet. Leipätekstissä käsitellään monesti erilaisia tapauksia, joita ei kuitenkaan eritellä tekstiä seuraavassa esimerkkilistassa. Näin esitellään esimerkiksi genetiivin ja nominatiivin käyttö yksiköllisen substantiivisen totaaliobjektin merkinnässä (s. 215-217), imperatiivin persoonapäätteet (s. 318-321) sekä joka- ja mikä-relatiivipronominien työnjako (s. 296-298). Esimerkkien erilaisuuden hahmottamista helpottaisi tapausryhmät erotteleva jäsentely ja niiden nimeäminen. Lisäksi esimerkkien pakottaminen joustamattomiin taulukkoasetteluihin on johtanut edellä mainitun sanojen katkeilun lisäksi paikoin häiritsevän pienen kirjasinkoon käyttöön (esim. s. 56, 130). Mietityttämään jää, seuraavatko äärimmäiset asettelut väistämättä suomen pitkistä sananmuodoista vai olisiko taiton huolellisempi viimeistely voinut auttaa asiaa.

Merkittävä parannus esimerkeissä suhteessa kirjoittajan moneen aiempaan kielioppiin (ks. esim. Karlsson 2004) on se, että ne on käännetty. Esimerkkejä ei kuitenkaan ole glossattu, joten lukija tarvitsee jonkin verran suomen taitoa niiden sanatarkkaan ymmärtämiseen. Ilmausten rakentumista avataan kylläkin aika ajoin kirjaimellisilla käännöksillä, mutta näiden käyttö voisi olla vielä systemaattisempaa. Esimerkiksi omistusrakenteellisella ilmauksella hänellä oli nälkä on vain käännös 'she/he was hungry', kun taas tuloslause pojasta kasvoi mies on selitetty idiomaattisen käännöksen lisäksi kirjaimellisesti 'of the boy grew a man' (s. 146). Esimerkkien täysi glossaaminen palvelisi parhaiten erityisesti kieliopin kohderyhmään kuuluvia kielentutkijoita, mutta ymmärrettävästi se olisi pidentänyt kokonaisuutta huomattavasti ja asettanut vielä suurempia haasteita taittajalle.

Systemaattisesti kielenaineksiin merkityistä ilmiöistä kantasanan ja johdoksen raja on tulkinnanvaraisin, sillä vastaan tulee väistämättä kysymys johdosten leksikaalistumisesta ja merkityksen idiomaattistumisesta (ks. esim. Kytömäki 1992; ISK $2004 \$ 166)$. Merkitykseltään idiomaattistuneita johdoksia (esim. käyttää ja ajatella, s. 304 ja 104) Karlsson ei merkitse johdoksiksi. Sen sijaan vakiintuneet mutta merkitykseltään läpinäkyvät johdokset on merkitty (esim. puhelin, s. 143). Tämä linja on varsin systemaattinen, ja vain pieniä kysymyksiä herää: onko esimerkiksi kannettava 'kannettava tietokone' niin idiomaattistunut ilmaus, ettei johtosuhdetta kantaverbiin kantaa tarvitse osoittaa (vrt. s. 143)?

\section{Oikeeta käytännön kielioppii}

Suomen opiskelijat toteavat usein, että suomen yleiskielen jälkeen täytyy opiskella toinen vieras kieli - suomen puhekieli. Karlsson pyrkii silloittamaan tätä kahden kielen dilemmaa nostamalla puhekielen variantteja esimerkkeihin alusta alkaen eikä näin ollen jätä aihetta vain viimeisen luvun varaan kuten aiemmissa kieliopeissaan. Hakasulkeissa annetut puhekieliset variantit on varustettu kieliopissa asteriskilla: esim. tä-tä ei sano-tta-isi [ ${ }^{*}$ sanotta $\left.(i) s\right]$, jos ei olisi [*o(l)is] aihe-tta (s. 342). Asteriksia käytetään kielitieteessä perinteisesti epäkieliopillisuuden merkkinä, minkä vuoksi sen käyttö puhekielen osoittimena voi herättää tahattomia assosiaatioita puhekielen virheellisyydestä suhteessa "oikeaan" kirjakieleen. Toisaalta tähän käyttötapaan - kuten myös aiemmin mainittuun heikon asteen merkintään plusmerkillä tottuu pian teosta lukiessa. Enimmäkseen puhekielisissä varianteissa on kyse lausumisen eroista (kuten merkintä kirjassa myös selitetään, s. xiii, xv) mutta aika ajoin myös rakenteellisista eroista, kuten lauseenvastikkeen ja sivulauseen vaihtelusta (s. 167). Edellä mainittu esimerkki havainnollistaa myös puhekielessä väistä- 
mättä vastaan tulevaa variaatiota. Vaihtoehtoiset variantit on kieliopissa esitelty sulkeiden avulla. Merkintätapa on tilaa säästävä, joskin jälleen lukijaa kuormittava.

Ennen varsinaista puhekielilukua 27 puhekielen piirteistä esitellään passiivimuotoisen verbin käyttö monikon ensimmäisen persoonan muotona (s. 114), mikä on ilmiön yleisyys huomioiden hyvä ratkaisu. Muut puhekielen fonologiset ja morfologiset ominaispiirteet esitellään luvussa 27, ja aiheesta kiinnostuneen lukijan olisikin hyödyllistä tutustua tähän osioon ennen esimerkkien läpi kahlaamista. Vaikka kielioppia ei välttämättä luetakaan lineaarisesti, olisi ensimmäisen puhekieltä sisältävän esimerkin kohdalla hyvä olla viite puhekielilukuun.

Luvun 27 alussa (s. 443) Karlsson tarttuu vanhaan väitteeseen "suomea puhutaan niin kuin sitä kirjoitetaan" ja toteaa sen pätevän foneemien ja grafeemien vastaavuuden osalta muttei yleisemmin. Tämä havainto toimii hyvänä johdatuksena puhekielen ominaispiirteisiin. Loppukahdennuksen ja n-äänteen muodostamat poikkeukset oikeinkirjoituksessa tulevat esiin jo äänteiden yhteydessä luvussa 2, minkä vuoksi on hieman hämmentävää, että myös loppukahdennus on esimerkeissä merkitty suoraviivaisesti puhekielisyysilmiöksi. Toisin kuin muut puhekielen piirteet loppukahdennus ei kuitenkaan ole kielellisen rekisterin ilmiö: vaikka sen käyttö varioikin hieman esimerkiksi alueellisesti, se kuuluu myös täysin yleiskieliseen puheeseen. Niin ikään hieman harhaan johtaa partitiivimuodon montaa merkintä muodon monta puhekielen variantiksi (s. 294), kun muodolla on myös yleiskielen normien mukainen oma käyttöalansa (Länsimäki 1995). Näistä epäjohdonmukaisuuksista huolimatta puhekielen huomioiminen läpi esimerkistön on pääosin toimiva ratkaisu.

\section{Yleisyys ja kontrastiivisuus punaisina lankoina}

Läpi kieliopin kulkee kaksi punaista lankaa, yleisyys ja kontrastiivisuus, joita kommentoin tässä järjestyksessä. Karlsson ohjaa lukijaa suhteuttamaan ilmiöitä ja yksittäisiä muotoja niiden käyttötaajuuksiin. Lukija oppii muun muassa, että astevaihtelu koskee 30:tä prosenttia suomen yhdistämättömistä perussanoista (s. 50), että lähes joka seitsemäs suomen johtamattomista sanoista on perusmuodon pohjalta taipuva $i$-päätteinen nomini (ns. $i-$ $i$-sana, s. 71) ja että pronominimuotojen (esim. niiden, noiden, heidän) lisäksi yleisimpiin monikon genetiiveihin kuuluvat ihmisten, suomalaisten, uusien ja naisten (s. 208). Tieto ilmiöiden yleisyydestä hyödyttää sekä kielestä yleisesti kiinnostunutta että sen oppijaa. Käytännön kielitaidon kehittämisen näkökulmasta se tarjoaa mahdollisuuden fokusoida keskeisimpään. Kaikki kieliopissa ei kuitenkaan heijastele yleisintä kielenkäyttöä, sillä esimerkiksi sananjohdon esittelyssä on joitain varsin uniikkeja tapauksia: sananmuotojen kiihtyvämmyys ja luetuttelee (s. 435) Googlehaut tuottavat arvion kirjoittamishetkellä vain yhden tuloksen - tämän kieliopin. Yleisyystietojen lähteeksi on kerran mainittu Kielitoimiston sanakirja, mutta useimmiten lähdetietoa ei ole.

Kontrastiivisia havaintoja Karlsson tekee sekä lausumisesta että kielen rakenteista. Vertailuparina ovat tällöin joko yksittäiset kielet (ääntämisessä enimmäkseen englanti ja välillä saksa) tai indoeurooppalaiset kielet yleisesti. Lausumisen osalta erityisen tärkeä on huomio ensitavun pääpainon pätemisestä myös vierassanoihin (s. 24-25). Kielen rakenteissa suomen ilmaisutapaa verrataan indoeurooppalaisten kielten toisenlaisiin strategioihin muun muassa suomelle tyypillisten genetiivi-ilmausten (esim. Suomen kansa, Niemisen perhe, s. 209) sekä dynaamisten verbi-ilmausten tapauksessa (esim. 
etsiä taskusta, jäädä Ruotsiin, s. 252-253). Vaikka kielioppi ei olekaan perustehtävältään kontrastiivinen, lisäävät tällaiset huomiot esityksen havainnollisuutta ja tukevat ennen kaikkea kielen oppimista.

\section{Kieli elää - niin kielioppikin}

Kielioppikirja on aina pysäytetty kuva kielen virrasta, niin kuin synkroninen kielen kuvaus yleisestikin. Kielen elävyydestä seuraa väistämättä, että jotkin ilmaukset jakavat äidinkielistenkin mielipiteitä. Nostan seuraavaksi esiin muutamia kieliopin esimerkkejä ja väitteitä, joiden jaettuus on vähintään rajallista.

Aloitetaan futuurin ilmaisukeinoista: Kuulun sukupolveen, jonka äidinkielen aineista tulla tekemään -muotoiset tulevaisuuden ilmaukset on merkitty punakynällä. Vaikka tätä rakennetta ei tarvitsekaan enää täysin tyrmätä, tuntuu Karlssonin tapa esittää se tasaveroisena vaihtoehtona preesensille (s. 313) tai jopa futuurin ensisijaisena ilmaisukeinona (s. 41) liiankin sallivalta (vrt. White 2006: 203204; KK 2015: 354-355). Toinen sallivuudessaan ihmetyttävä sääntö on, että pitkissä numeroissa olisi norminmukaista taivuttaa vain viimeistä numeroa (esim. kolmetuhatta satakahdella, s. 269-270). Tässä lienee toki tilanteista ja puhujakohtaista variaatiota, mutta nähdäkseni alkuosien taipumattomuus voisi sopia lähinnä puhekielisiin variantteihin.

Niin sanotussa on hauskaa -lausetyypissä esiintyy variaatiota predikatiivin sijassa: myös nominatiivi on mahdollinen (ks. esim. White 2006: 323). Karlsson ei käytä lauseesta mainittua nimitystä, mikä olisikin sellaisenaan mahdotonta, koska kieliopin vastaavissa esimerkeissä adjektiivi on hieman yllättäen lähes aina nominatiivissa: esim. on hauska uida $(\text { s. } 150,162)^{2}$, on vaikea ostaa talo (s. 217),

2. Tätä esimerkkiä käsitellään kieliopissa lisäksi ristiriitaisesti, sillä se analysoidaan toisaal- on vaikea oppia suomea (s. 346). Linja on yllättävä, koska rakenteen pääsääntönä esitetään yleensä adjektiivin partitiivimuoto, josta lyhyet ja yleiset adjektiivit voivat tehdä poikkeuksen tai olla vapaassa variaatiossa (White 2006: 322-323; KO 2015). Adjektiivit hauska ja vaikea voi toki tulkita juuri nominatiivinkin salliviksi lyhyiksi ja yleisiksi adjektiiveiksi, mutta tästä huolimatta partitiivivariantti ansaitsisi tulla nostetuksi esille paremmin kuin vain ohimennen muuta aihetta havainnollistavassa esimerkissä (on halvinta syödä puuroa, s. 390).

\section{Lopuksi: virheissä on eroja}

Olisi epärealistista odottaa, että viidensadan sivun kielioppi olisi virheetön. Valitettavasti teoksen viimeistelyn puutteet eivät rajaudu pelkkiin harmittomiin lyöntivirheisiin, vaan joukossa on myös oikeasti ymmärrettävyyttä haittaavia virheitä. Jo sinällään vaativien sijamuotojen, monikon genetiivin ja partitiivin, käsittelyihin on jäänyt sekavuuksia, jotka kenties johtuvat lukujen samanaikaisesta työstämisestä. Esimerkiksi monikon genetiiviä käsittelevässä luvussa annetaan yllättäen useammasta esimerkkisanasta vaihtoehtoisia partitiivimuotoja (s. 207), jolloin genetiivimuodot jäävät lukijalle arvoitukseksi. Kiusallisia ovat myös esimerkkien virheet, jotka muuttavat tarkoitetun muodon toiseksi (esim. Arto juokse juuri toiseen puhelimeen, s. 30o, lihavointi lisätty). Valitettavia vaikkakin sisällön oikeellisuuden kannalta harmittomampia viimeistelemättömyyksiä ovat leipätekstin ajoittaiset turhat toistot, jotka lienevät seurausta kiireisestä editoinnista (esim. s. 107-108, $202,205)$. Mainittakoon vielä, että vaikka internetosoitteet ovat aina riskialttiita painettavia niiden potentiaalisen muuttumi-

la (s. 150) subjektittomaksi lauseeksi ja toisaalla (s. 162) kompleksiseksi lauseeksi, jossa infinitiivi toimii subjektina. 
sen vuoksi, on silti pettymys, ettei esipuheessa (s. xiv) ja lähteissä (s. 496) mainittu kirjoittajan kotisivujen materiaalilinkki toimi vain muutama kuukausi kirjan painamisen jälkeen.

Kriittisten huomioiden jälkeen on lopuksi syytä kääntää katse siihen, että terminologialtaan ja esimerkeiltään ajantasaisen suomen kieliopin ilmestyminen kansainväliselle lukijakunnalle Routledgen sarjassa on hieno saavutus. Toivottavasti kirjasta ilmestyy tulevaisuudessa korjattu painos, josta sisältöä sekoittavat lapsukset on siivottu pois ja jonka luettavuutta on parannettu. Silloin paljon painavaa asiaa sisältävä teos pääsee todella oikeuksiinsa ja avaa suomen kielioppia havainnollisemmin kaikille kohderyhmilleen.

Jutta Salminen

juttamaaria.sukunimi@uni-greifswald.de

Kirjoittaja on suomen kielen lehtori Greifswaldin yliopistossa Saksassa ja suomen kielen väitöskirjatutkija Helsingin yliopistossa.

\section{Lähteet}

ISK = HAKUlinen, AUli - Vilkuna, Maria - Korhonen, Rittta Koivisto, Vesa - Heinonen, Tarja Ritt TA - AlHo, IRJA 2004: Iso suomen kielioppi. Helsinki: Suomalaisen Kirjallisuuden Seura.

Jönsson-Korhola, Hannele - White, LEILA 1997: Tarkista tästä. Suomen sanojen rektioita suomea vieraana kielenä opiskeleville. Helsinki: Finn Lectura.
Karlsson, Fred 1978: Finsk grammatik. Helsinki: Suomalaisen Kirjallisuuden Seura.

— 2004: Finnische grammatik. Kääntänyt Karl-Heine Rabe. Muokanneet Cornelius Hasselblatt \& Paula Jääsalmi-Krüger. Hamburg: Buske Verlag.

- 2010: Multiple final embedding of clauses. - International Journal of Corpus Linguistics 15 s. 88-105.

2015 [1999]: Finnish - An essential grammar. Routledge Essential Grammars. Kääntänyt Andrew Chesterman. Lontoo: Routledge.

KK 2015 = KORHONEN, RitTtA - MAAMIES, SARI (toim.) 2015: Kielitoimiston kielioppiopas. Kotimaisten kielten keskuksen julkaisuja 175. Helsinki: Kotimaisten kielten keskus.

KO 2015 = Kielitoimiston ohjepankki: Predikatiivi: on mukava vai mukavaa, että tulet? Kotimaisten kielten keskuksen verkkojulkaisuja 40. www.kielitoimistonohjepankki.fi/ohje/6o1 (14.4.2018).

КүтӧмёкI, LeENA 1992: Mikä on johdosten paikka? - Sananjalka 33 s. 7-3o.

LÄNSIMÄKI, MaIjA 1995: Montaa-partitiivi. - Kielikello 2/1995 s. 18-22.

PAjunen, Anneli 1999: Suomen verbirektioista. Yleisen kielitieteen julkaisuja 1. Turun yliopisto.

Routledge 2018: Routledge comprehensive grammar -sarjan internetsivu. https:// www.routledge.com/Routledge-Comprehensive-Grammars/book-series/SE0550 (19.3.2018).

White, Leila 2006: A grammar book of Finnish. Helsinki: Finn Lectura. 